\title{
Intra-EU Direct Investment and Enlargement
} Andrea Festa ${ }^{1}$

\begin{abstract}
This paper examines the determinants of the intra-EU direct investment (IDI) into the New Member States (NMS) using a panel dataset of bilateral capital flows for the period 1993-2013. It is found out by using a simple gravity model that EU membership is the most important determinant. Unlike previous studies including non-EU countries, the distance is insignificant, which is caused by proximity of these countries to one another. A separate analysis focused on subgroups of accession countries gives some evidence that even when size of their economy, distance, institutional quality and EU accession are taken into account, Central European countries receive more IDI than the Baltic and the Balkan states. On the contrary to that, the analysis restricted to the Balkan countries which have joined the EU shows the inexistence of a negative Balkans effect in attracting foreign investment. This finding is relevant because previous studies demonstrate a persistent negative Balkans effect for non-EU Balkan countries and suggests a crucial impact of the EU accession in determining the intra-EU capital flows.
\end{abstract}

Key words: Intra-EU direct investment, EU membership, New Member States

JEL Classification: C33, P27, P33

\section{Introduction}

The determinants of foreign direct investment (FDI) into the New Member States (NMS) of the EU have attracted much attention during the past decades, even before the EU accession. In the recent twenty years, Europe has seen historical developments in the ex-socialist countries and, in economic terms, a transition from socialism to free-market economies as well as an increasing FDI into these economies.

The EU enlargement policy helped this transition process, giving the basis of a common legislation across a wide range of subjects, including common trade and financial rules, customs union and free movement of workers, capitals and services. This process moved contemporaneously with the economic transition of these countries which share similar political and economic features. In fact, they all have faced institutional and social challenges in the 1990s, followed by economic reforms in order to comply with the EU legislation.

\footnotetext{
${ }^{1}$ Italian Customs and Monopoly Authority, Regional Directorate of Lombardy, Office of Milan 2, via Valtellina 1, 20159 Milan, Italy. Email: andrea.festa@agenziadogane.it. I would like to thank two anonymous reviewers for their valuable comments. The views expressed in this paper are those of the author and do not necessarily reflect those of the Italian Customs and Monopoly Authority.
} 
The goal of this paper is to analyze the determinants of the intra-EU direct investment (IDI) into NMS, for which panel data on bilateral capital flows from EU-15 countries to NMS during the period 1993-2013 will be used. Because the most important part of the FDI into the transition economies comes from the developed Europe, as showed by Bevan and Estrin (2004), the analysis is focused on the determinant of IDI to investigate which are the main factors driving the capital flows in the continental Europe with a special regard to the EU membership for the transition economies to be considered the symbol of the re-integration into the developed Europe. In fact, the perspective and, more importantly, the accession to the EU can be crucial in determining the capital flows into the NMS.

The paper is organized as follows: Section 1 introduces the issue of IDI into the European transition economies. Section 2 provides a brief overview of the literature, and Section three illustrates data and empirical specification. Section 4 highlights the results, and finally, Section 5 concludes.

\section{Literature}

A number of studies investigated the determinants of capital flows into the ex-socialist European countries during the transition phase (for instance, Baldwin et al., 1997; Bartlett, 2008; Bevan and Estrin, 2004; Bevan, Estrin and Mayer, 2004; Brenton et al, 1997; Buch et al., 2003; Dikova and van Witteloost, 2007; Di Mauro, 1999; Estrin and Uvalic, 2013; Estrin, Xavier and Brada, 2000; Lankes and Venables, 1996; Meyer and Estrin, 2004; or Richet and Brada, 2000).

Some papers focus on the key determinants of FDI into the transition economies by analysing forms and origins (Hunya 2011, 2012; Kalotai, 2010). Brada et al. (2006) show that the Balkan countries which experienced political transition problems receive less FDI compared to the Central-European and Baltic countries.

Bevan and Estrin (2004) investigate the determinants of FDI into the ex-socialist European economies and find out that unit labour costs and gravity factors are important in affecting the capital flows. Furthermore, they came to the conclusion that the announcement about the EU accession has a positive impact on the capital inflows. In fact, it is perceived as an important step that is achievable only after substantial economic and political reforms. In general, the process took time so the announcement itself should be considered a crucial achievement for a transition country.

Estrin and Uvalic (2013) found out that Western-Balkan countries receive less FDI compared to countries of Central East Europe (CEEC) even when market size, distance and EU accession are taken into account. The authors suggest that this difference is due to the inadequate level of the public institutions, the heritage of a historical fragmentation, current political risks and the economic environment, too, in which the protection of property rights has not yet reached the level of more developed economies.

Garibaldi et al. (2001) ascertained that market size, availability of resources, openness and barriers to investment are significant determinants of capital flows, whereas wages, initial liberalization and initial condition do not seem to play the key role. 
Furthermore, Barrell and Pain (1999) find out that positive initial conditions play a role in determining capital inflows by attracting significant FDI at the early stage of transition as well as supporting economic development and growth.

Uvalic (2003) and Brada, Kutan and Yigit (2006) stress the fact that political instability negatively affects the investment flows, especially for the region of the Balkans, where there are still important and unresolved political issues. These findings are substantially confirmed by Demekas et al. (2005).

On the other hand, Kekic (2005) finds out that the determinants of FDI for the Balkans are equivalent to other ex-socialist economies even if the analysis does not cover the whole transition phase.

Despite consistent literature on this topic is abundant, there is still a lack in the investigation of the intra-EU direct investment (IDI) from EU-15 member states into the transition countries. Because several NMS joined the EU during the last decade, now it is possible to check the importance of the EU membership in determining the capital inflows after some time since the accession. IDI, as well as FDI, can be crucial to accelerate and complete the transition to free market economies (see, for instance, Mayhew 1998). Moreover, because some group of countries share similar social and institutional features, it is possible to investigate whether some subgroups of NMS have benefited from the EU membership more than others and, if so, to which extent.

\section{Data and methodology}

In this paper, the data have been drawn from the comprehensive and comparable Eurostat database for $27 \mathrm{EU}$ member states for the period 1993-2013. Observations of IDI are in thousands of Euros and describe the direct investment flow from an EU-15 country to a NMS. The dataset includes 2506 observations and covers the full period of transition so it is possible to have a complete framework of what has been the effect of the EU accession on intra-EU direct investment. EU-15 countries are the source economies, ex-socialist countries that were involved in the enlargement process are the host economies. Current official and potential candidates, as well as the 28th EU member state (Croatia) have been excluded from the final sample because of insufficient data, especially for the Western-Balkan countries. In order to study the impact of the EU accession on IDI, the focus is therefore on transition economies that joined the EU during the last decade (that is, Bulgaria, Czech Republic, Cyprus, Estonia, Hungary, Latvia, Lithuania, Malta, Poland, Romania, Slovakia, and Slovenia). In fact, the EU membership can be viewed as a signal of development and democratization, albeit as regards to market size, institutional development and the degree of assimilation of the acquis communitaire (Bevan and Estrin, 2004), there are lingering differences between the old and new member states. Nevertheless, the EU membership allows to directly investigate on how accession affected the economies under observation by considering the bilateral investment flows as an appropriate signal of integration and development.

On the other hand, European association agreements were not taken into account because of multicollinearity issues. These agreements might be considered a part of the pre-accession phase. As a consequence, their role is considered to be captured by the EU membership dummy in the empirical estimates. 
The idea underlying this paper is that the more the continental Europe will experiment with large capital flows between old and new member states, the more these economies will become integrated and developed. One of the main objectives of the enlargement policy is to establish common grounds of rules allowing the EU enterprises to operate without barriers in any member state. The goal is to ensure as much as possible same opportunities to do business all over the European Union, regardless of the enterprises' country of origin. The EU membership is a symbol of stability of a country, quality of its institutions as well as implementation of political reforms. Thus, investors consider it the most important signal that an ex-socialist country can send. In fact, even if the enlargement process includes several progressive steps, it is only at the moment of the accession that a candidate country demonstrates that it fulfils all the conditions to be part of the developed EU. Thus the EU membership reduces the country risk and it is expected to positively affect the inward capital flows, albeit the accession could be a better signal for extra-EU rather than intra-EU foreign investors.

However, despite the EU membership the IDI flows can be limited by gravity factors. In general, the greater is the distance between two countries, the lesser should similarities be, for instance, at social and cultural level, and the lesser should the bilateral trade and investment flows be, too. As stated by Bevan and Estrin (2004), the distance is a measure of transactional cost of doing business abroad. Moreover, the IDI flows are expected to be influenced by market size of the involved economies as well as by distance. In order to investigate whether or not the IDI flows are determined by gravity factors, a simple gravity model was used.

The gravity approach is used widely in literature. It assumes that the size of economies, the distance between source and host countries and other factors (unit labour cost, institutional and social stability, or membership in economic associations, for instance) are the main drivers for trade or investment flows. In line with recent research, this approach was adopted to investigate the determinants of the bilateral investment flows between the old and new EU member states. Following Helpman (1984), Brainard (1997) and Bevan and Estrin (2004), the model controls for different variables typically used to capture comparative advantages in the NMS, and has the following form [Eq.1]:

$$
\begin{aligned}
\operatorname{lnIDI}_{i i t}=\beta_{0} \operatorname{lnGD}_{i t}+\beta_{1} \operatorname{lnGDP}_{j t}-\beta_{2} \text { Indistance }_{i j}+\beta_{3} \text { lnopenness }_{j t} \\
\\
-\beta_{4} \text { lnRULC }_{j t}+\beta_{5}{\text { Membership } 2004_{j}+\beta_{6} \text { Membership } 2007_{j}} \\
+\beta_{7} \text { Institutions }_{j}+\varepsilon_{i j t}
\end{aligned}
$$

where the subscript $i$ stands for the source country, $j$ stands for the host country, and finally $t$ for year. Any variable entering the equation provided above is in logs, except for the distance variable and the membership dummy. The IDI from a source EU-15 country to a host NMS is the dependent variable. On the right hand side (RHS) of the equation [1], $G D P_{i t}$ is the size of the source country; $G D P_{j t}$ is the size of the host country; distance $_{i j}$ stands for the distance from the capitals (in kilometers); openness $s_{j t}$ stands for the sum of total import and export over GDP of the host country; $R U L C_{j t}$ stands for the real unit labor cost of the host country; Membership2004 ${ }_{j}$ is the EU accession dummy variable which assumes the value of 0 before 2004 and then 1 for the Czech Republic, Cyprus, Estonia, Hungary, Latvia, Lithuania, Malta, Poland, Slovakia and Slovenia; Membership2007 is the EU accession dummy variable that assumes the value of 0 be- 
fore 2007 and then 1 for Bulgaria and Romania ${ }_{j}$; Institutions $s_{j}$ considers a measure drawn by the Heritage Foundation's Index of Economic Freedom: the investment freedom index (Estrin and Uvalic, 2013); and finally $\varepsilon_{i j t}$ is the error term. The model is estimated with random effects because the Hausman test does not reject the null hypothesis of hortogonality between regressors and the error term. The model controls for gravity factors and for factors of cost and market conditions. The variables are in logs to address non-linearities of the data (Estrin and Uvalic, 2013). Due to the fact that investment decisions take time and are not influenced by the RHS variables immediately, the model was estimated with a lag of one period in the independent variables, the only exception being the constant. This appears to be a reasonable assumption especially as regards time consuming decisions such as the decision of investing abroad. Moreover, it helps us address potential endogeneity issues.

With regard to the RHS variables, the coefficients for both GDP and openness variables are expected to be positive related to IDI because market size and openness of the economies should be thought of as signals of the capacity to supply and development (Bevan and Estrin, 2004). On the other hand, the higher the factor costs are in a host country compared to the factor costs of the source country, the less an enterprise of the source country is motivated to invest there. Thus the coefficient of the real unit labor cost for the host country is expected to negatively affect investment flows. The distance variable is a proxy for transnational costs (in economic and social terms, i.e. different cultures, languages, etc.). It holds true that the greater the distance between source and host countries, the higher the transnational costs are expected to be. Hence, the coefficient of this variable should be negatively related to IDI. Vice versa, the EU membership dummy as a signal of institutional stability and economic development should positively affect the dependent variable and the investment freedom index.

In order to detect heteroskedasticity, White's and Breusch-Pagan/Cook-Weisberg's tests for heteroskedasticity were performed. They evidence the presence of heteroskedasticity in the residuals of the main model. Moreover, as far as autocorrelation is concerned, the Cumby-Huizinga general test for autocorrelation was performed with the null hypothesis of no serial correlation or that serial correlation exists, but died out at a known finite lag $(q>0)$. The test can be used in cases where alternatives such as the BoxPierce/Ljung-Box, Durbin's h test and the Breusch-Godfrey test are not applicable. For example, the Box-Pierce/Ljung-Box is not applicable if regressors are not strictly exogenous and there is heteroskedasticity in the residuals. The Breusch-Godfrey test as well as the Durbin's h test, relaxes the assumption of strictly exogenous regressors but are inappropriate in presence of conditional heteroskedasticity. The Cumby-Huizinga test is advantageous in the fact that it can be applied in the fixed-T large-N panel data context. The test rejects the null hypothesis of no serial correlation in the residuals. Therefore, because the residuals may exhibit heteroskedasticity and autocorrelation, the model was estimated correcting for heteroskedasticity and within-cluster correlation in order to obtain cluster-robust standard errors and mitigate the problem of autocorrelation. This method was chosen because the main specification shows some differences between the cluster-robust and default standard errors. In this case, cluster-robust estimation should be preferred. 
On the other hand, the estimator proposed by Driscoll and Kraay (1998) - that is robust to heteroskedasticity, both within and across cluster correlations and that has the advantage that correlations across clusters are possible - was not used because the asymptotics of its standard errors require a larger number of time periods. The NeweyWest/Bartlett kernel (HAC) estimator was not used either because it requires large-T asymptotics.

The data was clustered at the state level, with residuals assumed to be uncorrelated across clusters but correlated within a cluster. In other words, the residuals in different periods for a given state may be correlated, while the residuals for different states are assumed to be uncorrelated. It should be noted that, in general, if observations are correlated over time, cluster-robust standard errors account even for such serial correlation. However, as a robustness check, the data were clustered in the $\mathrm{N}$-dimension, that is, on panel units in order to obtain standard errors robust to arbitrary serial correlation. The main findings remain unaltered.

\section{Results}

The analysis of determinants of the intra-EU capital flows into the new member states is based on the assumption that the EU membership positively affects IDI while gravity factors, such as the distance between the source and host countries negatively affects the investment flows. Furthermore, factor costs, size and openness of the countries involved should play a role in this contest (in a negative and positive manner, respectively).

Table 1 shows the annual investment flows into the NMS. At a first glance, it is possible to see substantial increase in investment flows after 2000 for all the transition economies. This is a result of macroeconomic and political stability. Despite the fact that the EU accession is a better signal for extra-EU rather than intra-EU foreign investors, even the intra-EU investment flows benefited from the EU enlargement. Table 1 shows that in comparison to 2003, capital flows into the NMS increased twice during the accession phase (2004 - 2007). Moreover, the year after the second enlargement (Romania and Bulgaria, 2008), capital flows into the NMS reached their historical peak. These flows decreased due to global economic crisis after that year. Nevertheless, they were always larger compared to the last year before the first enlargement (2003). Thus, it is possible to state that the EU accession reduced the country risk even in case of IDI flows. The increase in investment flows widened after the first enlargement (2004) for several countries, albeit with differentiation. It should be underlined that all the NMS attracted more IDI in comparison to the 1990s. On the other hand, the second enlargement, which was restricted to Bulgaria and Romania, did not impact investments flows of these countries in any notable manner, especially for Bulgaria. The reason for that can be seen in the economic crisis that caused a fall in IDI after 2007-2008 in most ex-socialist countries.

Table 2 illustrates the top three source countries in each NMS, and provides an analysis of the latest year available (2012). In the group of countries that represented major investors in at least three NMS, there is only the Netherlands (Cyprus, Hungary and Slovakia). Denmark (Czech Republic and Romania), Spain (Malta and Poland) and Sweden (Estonia and Latvia) are major investors in two NMS, while Luxembourg (Bulgaria), 
Belgium (Slovenia) and Germany (Lithuania) are major investors in one country. This could suggest that distance may play a role in determining the IDI flows. In fact, Spain and two Nordic countries (Denmark and Sweden) are to be found among the top source countries. In comparison to mainland Europe, these countries are relatively more distant to the NMS. On the other hand, it should be noted that the most important EU economy (Germany) is the top investor in one country only. Here, it should be underlined that an enterprise can opt to invest as well as to export without investing abroad. This is especially valid for enterprises of countries that are export-oriented economies, such as Germany.

Figure 1 illustrates the sectoral distribution of the IDI flows. The data have been aggregated into the agriculture, mining, manufacturing and services sector of the NMS in 2011. This analysis can be useful in evaluating the long-run impact of the capital flows on employment and growth (Estrin and Uvalic, 2013). At a first glance, it is possible to see that the services sector collects substantial capital flows, on average 59 percent of total. In particular, this sector represents more than $75 \%$ in Hungary, while lower shares were registered in other countries (47\% in Romania, 51\% in Slovakia, and $52 \%$ in the Czech Republic). As far as manufacturing is concerned, there is an important differentiation among the NMS. In fact, compared to other ex-socialist economies, the Central NMS (the Czech Republic, Slovakia and Poland) attracted a substantial amount of IDI in the manufacturing sector (more than $68 \%$ of total).

Table 3 shows the main results. It should be noted that in all specifications, any variable entering the eq. [1] has the expected sign, with the exception of the investment freedom index. This index is insignificant, though. Column (1) illustrates the empirical specification without the EU membership dummies. As expected, the coefficient of the distance variable (-.018) is negative. However, it is insignificant. This result diverges from the previous studies - which include extra-EU countries as source economies - but is not surprising given the proximity of the countries to each other.

The model is estimated including the EU membership 2004 dummy in Column (2). The coefficients of the other variables do not change significantly. More importantly, it should be noted that the EU membership dummy is the main determinant of the IDI flows as shown by its magnitude (.208). The distance, on the other hand, does not play the key role in determining investment flows into the NMS. In fact, the coefficient reaches a value close to zero (-.006) and is statistically insignificant. The size of the source economies is always positive and significant (from .047 to .050; Table 1) while the size of the host economies and openness of the host countries to world trade seems not to have any crucial impact on determining the investment flows. The same reasoning is valid to factor costs measured by real unit labor costs whose coefficient in any specification is negative but insignificant. It is necessary to say that this was expected.

The model is estimated including both the EU membership 2004 and 2007 dummies in Column (3). The coefficients of the RHS variables do not change much. Once again, the EU membership 2004 and 2007 dummies are the main determinants of the intra-EU capital flows as shown by their magnitude (.253 and .424 , respectively) and significance at $1 \%$. 
Column (4) presents the results adding the investment freedom index among the independent variables as a measure of institutional quality. The results remain unchanged albeit the coefficient of the investment freedom variable is insignificant as in the work of Estrin and Uvalic (2013). Thus the impact of the institutional qualities is - not surprisingly - fully absorbed by the EU membership dummies.

Our variable of interest, EU membership dummies, retains its significance and magnitude (.258 and 424, respectively). If we were to put it another way, even when controlling for other institution variables, the EU membership is the main determinant for IDI flows while the distance between the source and the host countries does not play the key role. Interestingly, the IDI flows to the NMS in any specification do not seem to be significantly affected by the size market of the host countries while the size market of the source countries is positive and significant. Real unit labor costs and openness show insignificant coefficients. These results partly contrast with the previous findings (Bevan and Estrin, 2004), especially with regard to the factor costs, even if the coefficients of both GDPs are similar. However, it should be noted that the authors in their paper investigated the determinant of foreign direct investment into transition economies, including capital flows from non-EU countries, such as US or Japan.

Furthermore, because table 7 shows that there are some issues of collinearity - for instance, among the institutional variables and the EU membership as well as among distance and GDP variables - and in order to investigate the impact of collinearity on the results, the model was estimated by adding one or several regressors at a time; after doing this, the main findings did not change.

Table 4 illustrates the results related to the Baltic countries (Estonia, Latvia, and Lithuania). The recent history of these countries is similar in political, social and economic terms, which allows us to consider them a sub-group of the NMS, and to proceed with a separate analysis. By focusing our attention to these young democracies, it is possible to see that, once again, the coefficients of all the explanatory variables have the expected sign, with the exception of the investment freedom index because of collinearity. The EU membership dummies for 2004 and 2007 are significant at $1 \%$ and have notable magnitude. Hence, the EU accession was vital in attracting IDI for this subgroup of countries, too. Source GDP and openness show significant coefficients at $10 \%(.046$ and .009 , respectively). On the contrary, the Baltic dummy is negative (-.028 and -.027 , respectively in column 1 and 2), therefore suggesting that being a Baltic country could negatively affect the investment flows. Because the distance is statistically insignificant, this impact should not be attributed to geographic reasons. In fact, it should be noted that among the NMS, these economies were the only ex-socialist countries which had once been a part of the USSR. In comparison to other NMS, these disadvantageous initial conditions can be interpreted as more pronounced political barriers to investment from the rest of Europe.

Table 5 restricts the analysis to the Balkan countries (Bulgaria, Romania, Slovenia and Hungary). Once again, the EU membership dummies are the main determinants of the IDI flows with coefficients significant at $1 \%$ while the coefficient of the source GDP is significant at 10\% (.047 and .046, respectively in column 1 and 2) and the distance is negative but insignificant. More importantly, the coefficient of the Balkans dummy is close to zero (-.006 and -.007 in column 1 and 2, respectively). Thus, the analysis re- 
stricted to the Balkan countries that joined the EU demonstrates the inexistence of a negative Balkans effect in attracting IDI. This finding is remarkable because previous research identified a persistent negative Balkans effect for non-EU Balkan countries (Estrin and Uvalic, 2013).

The study restricted to the countries of Central Europe (the Czech Republic, Slovakia and Poland) confirmed the results of the main model (Table 6). Even for these economies the EU membership is the main determinant of the IDI flows with coefficients of notable magnitude and significant at $1 \%$. Source GDP and openness have coefficients significant at $10 \%$, whereas the distance is insignificant. In particular, unlike the analysis focused to the other subgroups, the Central dummy is positive (.016 and .015 , respectively in column 1 and 2), which suggests that even when market size, distance, factor costs, institutional quality and EU membership are taken into account, countries of Central Europe receive more IDI in comparison to the Baltic and Balkans ones. As has been mentioned, the reason could be that the Central NMS attract substantial amount of IDI in manufacturing sector. This sector usually needs more investment compared to the services sector. Moreover, it could better support industrial restructuring, structural changes and employment creation (Estrin and Uvalic, 2013). However, the Baltic and Balkan countries receive substantial amount of IDI in the services sector. This could help explain why the Central NMS received more IDI flows than the other two subgroups of transition countries. However, because all the subgroup dummy variables show insignificant coefficients, this interpretation should be taken with caution. Vice versa, the coefficient of zero related to the Balkans dummy demonstrates that being part of the EU eliminated any negative Balkans effect in attracting intra-EU investment. This is an important finding because previous research (Estrin and Uvalic, 2013) suggested that a negative Balkans effect in attracting foreign investment still persisted for non-EU Balkan countries.

\section{Conclusions}

Using a gravity approach covering the period 1993-2013 with data extracted from the Eurostat database, this paper investigates the determinants of the intra-EU direct investment flows into the NMS. The analysis is focused on 27 EU countries divided into source economies (the EU-15 countries) and host economies (the NMS that entered the EU on 2004 and 2007). The paper extends the period analyzed by previous research and gives evidence that the main determinants of the investment flows between EU-15 countries and NMS are represented by the EU accession. Thus, the membership in EU is a crucial signal of institutional and macroeconomic stability in order to plan direct investments into the NMS by other EU enterprises.

Moreover, in contrast to the existing literature that evidences the importance of openness as a determinant of foreign direct investment, in this paper this variable is not crucial in determining the IDI flows because is substantially absorbed by the EU membership that, among other things, requires free circulation of goods and services, customs union and the adoption of a common EU legislation with regard to trade rules. This probably helps explain why this variable is positive, as expected and as it was in previous studies, but statistically insignificant in the main specification. As far as the market size is concerned, and in line with previous research, the results suggest that GDP of the 
source country is important in determining the IDI flows. Vice versa, GDP of the host countries as well as real unit labor cost do not seem to play a key role.

Differently from previous works, the distance is - not surprisingly - statistically insignificant. The reason is to be seen in the proximity of these countries to one another. On the other hand, even this variable is captured by the EU membership for the same reasons related to openness. This is valid also for measures of institutional quality such as the investment freedom index that is fully absorbed by the EU membership dummies.

A separate analysis on three subgroups of NMS - sharing similar political, social and economical features - shows that even when market size, distance, institutional quality and EU membership are taken into account, the Baltic and Balkan countries continue to receive less IDI than Central ones. With regard to the Baltic countries, the reason is to be found in the initial conditions of these economies. In fact, when the transition from socialism to free market economies started, they are the only states which had been a part of the USSR. This might suggest more pronounced political barriers that during the transition process limited the investment flows from Western Europe. With regard to the Central NMS, they probably receive more IDI compared to the Baltic and Balkan countries because they attract substantial amount of IDI in the manufacturing sector that needs more capital compared to the services sector in which the Baltic and Balkan countries receive the most important part of IDI. However, these results should be taken with caution because the related coefficients are insignificant.

On the other hand, the analysis restricted to the Balkan countries which have joined the EU does not evidence any negative Balkans effect in attracting IDI. This finding is important because previous studies show a persistent negative Balkans effect for nonEU Balkan countries. Thus, the results suggest that the EU membership is crucial for the EU Balkan countries in order to eliminate any negative Balkans effect in attracting intra-EU capital flows.

\section{References}

BALDWIN R., FRANCOIS J. and PORTES R. (1997). The costs and benefits of eastern enlargement: The impact on the EU and Central Europe. Economic Policy 24, 125170 .

BARRELL, R. and PAIN N. (1999). Domestic institutions, agglomerations and foreign direct investment in Europe. European Economic Review 43, 925-934.

BEVAN A. and ESTRIN, S. (2004). The determinants of foreign direct investment into European transition economies. Journal of comparative economics 32 775-787.

BEVAN A., ESTRIN, S. and MEYER K. (2004). Foreign investment location and institutional development in transition economies. International Business Review 1, 43-64.

BOX G.E.P. and PIERCE D.A. (1970), Distribution of residual autocorrelation in autoregressive-integrated moving average time series models, Journal of the American Statistical Association, 65, 1509-1526.

BLONINGEN B. A. (2005). 'A review of the empirical literature on FDI determinants', Atlantic Economic Journal, 33, pp. 383-403. 
BRADA J.C., ALI M. KUTAN and TANER M. YIGIT (2006). 'The effects of transition and political instability on foreign direct investment inflows: Central Europe and the Balkans', Economics of Transition, 14 (4), pp. 649-680.

BRAINARD, S. L. (1997). An empirical assessment of the proximity-concentration trade-off between multinational sales and trade. American Economic Review 87, 520544.

BRENTON P., DI MAURO F. and LÜCKE M. (1999). Economic integration and FDI: An empirical analysis of foreign investment in the EU and in Central and Eastern Europe. Empirica 26, 95-121.

BREUSCH T.S. and GOFFREY L. (1981), A review of recent work on testing for autocorrelation in dynamic simultaneous models, Macroeconomic Analysis, ed. by Currie D., Nobay R. and Peel London D., Cron-Helm.

BREUSCH T.S. and PAGAN A.R. (1979). A Simple Test for Heteroskedasticity and Random Coefficient Variation, Econometrica 47 (5), 1287-1294.

BUCH C., KOKTA R. and PIAZOLO D. (2003). Does the East get what would otherwise flow to the South? FDI diversion in Europe. Journal of Comparative Economics 31, 94-109.

COOK R. D. and WEISBERG S. (1982). Residuals and influence in regression. Chapman and Hall, New York-London.

CUMBY R. E. and HUIZINGA J. (1990), Testing the autocorrelation structure of disturbances in ordinary least squares and instrumental variable regressions NBER Technical Working Paper 90.

DEMEKAS, D.G., BALAZS H., RIBAKOVA E. and YI WU (2005). 'Foreign Direct Investment in Southeastern Europe: How (and how much) can policies help?', IMF Working Paper 05/110

DIKOVA D. and VAN WITTELOOSTUIJN A. (2007). 'Foreign direct investment mode choice: entry and establishment modes in transition economies', Journal of International Business Studies, 38, pp. 1013-1033.

DI MAURO F. (1999). The effects of economic integration on FDI flows: an empirical analysis and comparison with trade. Document paper No. 134. Center for European Policy Studies, Brussels.

DRISCOLL J.C. and KRAAY, A.C. (1998). Consistent Covariance Matrix Estimation with Spatially Dependent Panel Data. The Review of Economics and Statistics, 80(4), 549-560.

DURBIN J. (1970). Testing for serial correlation in least squares regression models when some of the regressors are lagged dependent variables, Econometrics, 21, 333-55.

ESTRIN S. and UVALIC M. (2013). Foreign direct investment into transition economies: Are the Balkans different? LSE 'Europe in Question' Discussion Paper Series.

ESTRIN, S., XAVIER R. and BRADA J. (2000). Foreign Direct Investment in Central Eastern Europe: Case Studies of Firms in Transition, Armonk and London: M. E. Sharpe. 
GARIBALDI, P., MORA, N., SAHAY, R., AND ZETTELMEYER, J. (2001), What Moves Capital to Transition Economies?, IMF Staff Papers, Vol. 48, Special Issue.

HUNYA G. (2011). 'Diverging patterns of FDI recovery', in WIIW Database on 2011 Foreign Direct Investment in Central, East and Southeast Europe, Vienna: The Vienna Institute for International Economic Studies.

HUNYA, G. (2012). 'Short-lived recovery', in WIIW Database on 2012 Foreign Direct Investment in Central, East and Southeast Europe, Vienna: The Vienna Institute for International Economic Studies.

JANICKI, P.H. and WUNNAVA V.P. (2004). 'Determinants of foreign direct investment: empirical evidence from EU accession candidates', Applied Economics, 36, pp. 505-509.

KALOTAY K. (2010). 'Patterns of inward FDI in economies in transition', Eastern Journal of European Studies, 1 (2), pp. 55-76.

KEKIC L. (2005). 'Foreign direct investment in the Balkans: recent trends and prospects, Journal of Southeast European and Black Sea Studies, 5.

LANKES H.K. and VENABLES A.J. (1996). 'Foreign direct investment in economic transition: the changing pattern of investments', Economics of Transition, 4 (2), pp. 331-347.

MAYHEW A. (1998). Recreating Europe. Cambridge Univ. Press, Cambridge.

RESMINI L. (2001). The determinants of foreign direct investment into the CEECs: new evidence from sectoral patterns. Economics of Transition 8, 665-689.

UNCTAD. World Investment Report 2011, available on-line.

UVALIC M. (2003). 'Economic Transition in Southeast Europe", Southeast European and Black Sea Studies, 3 (1), pp. 63-80.

WHITE H. (1980), A Heteroskedasticity-Consistent Covariance Matrix Estimator and Direct Test for Heteroskedasticity, Econometrica, 48(4 - May), 817-838. 


\section{Appendix 1: Tables and Figures}

Table 1 Annual IDI Flows to the New Member States

\begin{tabular}{ccccccccccc} 
& 1993 & 1994 & 1995 & 1996 & 1997 & 1998 & 1999 & $\mathbf{2 0 0 0}$ & $\mathbf{2 0 0 1}$ & $\mathbf{2 0 0 2}$ \\
\hline Bulgaria & 10 & 112 & 10 & 70 & 91 & 193 & 127 & 509 & 187 & 1014 \\
Cyprus & 5 & 28 & 1 & 42 & -90 & 126 & -206 & 73 & -224 & 211 \\
Czech Republic & 854 & 1210 & 2548 & 1582 & 2010 & 2298 & 1620 & 2876 & 2709 & 2024 \\
Estonia & 5 & -3 & 11 & 20 & 47 & 77 & 313 & 213 & 246 & 188 \\
Hungary & 1335 & 928 & 3148 & 1871 & 1859 & 3332 & -110 & 2892 & 1870 & 149 \\
Latvia & 3 & 12 & 26 & 19 & 48 & 71 & 94 & 55 & 85 & -22 \\
Lithuania & 5 & 7 & 27 & 16 & 31 & 99 & 235 & 125 & 175 & 198 \\
Malta & 18 & 12 & 5 & 300 & 36 & -45 & 103 & 8 & 63 & 23 \\
Poland & 749 & 906 & 1472 & 3455 & 3325 & 5945 & 6913 & 8230 & 5985 & 1865 \\
Romania & 26 & 26 & 99 & 137 & 445 & 530 & 523 & 638 & 770 & 537 \\
Slovakia & 90 & 182 & 123 & 399 & 331 & 437 & 456 & 1460 & 1033 & 3899 \\
Slovenia & 65 & 38 & 121 & 98 & 208 & 203 & 258 & 234 & 429 & 1063 \\
\hline
\end{tabular}

Source: Author's elaborations based on Eurostat data. Values in millions of euros.

Table 1 Contiuned

\begin{tabular}{ccccccccccc} 
& $\mathbf{2 0 0 3}$ & $\mathbf{2 0 0 4}$ & $\mathbf{2 0 0 5}$ & $\mathbf{2 0 0 6}$ & $\mathbf{2 0 0 7}$ & $\mathbf{2 0 0 8}$ & $\mathbf{2 0 0 9}$ & $\mathbf{2 0 1 0}$ & $\mathbf{2 0 1 1}$ & $\mathbf{2 0 1 2}$ \\
\hline Bulgaria & 113 & 162 & 1301 & 846 & 2173 & 2827 & 1671 & 633 & 466 & 170 \\
Cyprus & 25 & 504 & 2112 & 2214 & 6088 & 5955 & 43411 & 1605 & 1480 & 30751 \\
Czech Republic & -691 & 1195 & 3889 & 4480 & 5289 & 4983 & 2248 & 4121 & 1760 & 3949 \\
Estonia & 233 & 520 & 2510 & 605 & 448 & 1346 & 1177 & 891 & -2287 & 232 \\
Hungary & 2953 & 4893 & 16187 & 4107 & 13600 & 6720 & -13557 & 7710 & 173 & -3403 \\
Latvia & -174 & 235 & 21 & 105 & 319 & 759 & -24 & 314 & 906 & 175 \\
Lithuania & 233 & 228 & 138 & 258 & 132 & 871 & 101 & 466 & 532 & 216 \\
Malta & 522 & 725 & 4213 & 12174 & 1866 & 3469 & 4570 & 492 & -4543 & -3629 \\
Poland & 1663 & 6827 & 3485 & 8451 & 9529 & 7667 & 5760 & 6818 & 8781 & 5278 \\
Romania & 558 & 2744 & 2002 & 8669 & 4827 & 10756 & 1758 & 1913 & 1113 & 2012 \\
Slovakia & -1052 & 1017 & 1422 & 1763 & 1544 & 2117 & 1682 & 1240 & 948 & -2914 \\
Slovenia & 643 & 269 & 575 & 507 & 760 & 2859 & -35 & 169 & 532 & -678 \\
\hline
\end{tabular}

Source: Author's elaborations based on Eurostat data. Values stated in millions of $€$. 
Table 2 IDI Flows by Source Country (2012)

Country of destination

Top 3 source countries

\begin{tabular}{lc}
\hline Bulgaria & Luxembourg - Netherlands - Denmark \\
Cyprus & Netherlands - Belgium - France \\
Czech Republic & Denmark - Ireland - Netherlands \\
Estonia & Sweden - Ireland - Netherlands \\
Hungary & Netherlands - Spain - Finland \\
Latvia & Sweden - UK - Ireland \\
Lithuania & Germany - Sweden - Spain \\
Malta & Spain - UK - Luxembourg \\
Poland & Spain - Netherlands - Denmark \\
Romania & Denmark - Spain - Netherlands \\
Slovakia & Netherlands - Spain - Luxembourg \\
Slovenia & Belgium - Denmark - Luxembourg \\
\hline
\end{tabular}

Source: Eurostat. 
Figure 1 Foreign Direct Investment by Economic Activity, 2011

Clockwise from the top: Agriculture (blue), Mining (red), Manufacturing (green) and Services (purple)

Bulgaria

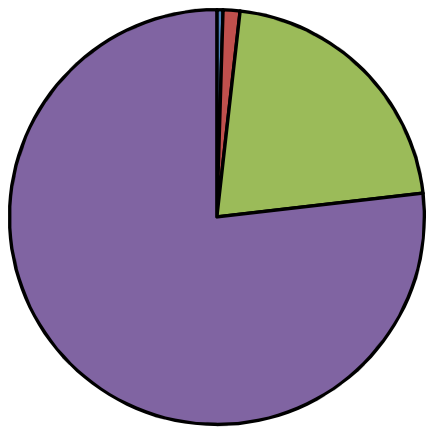

Estonia

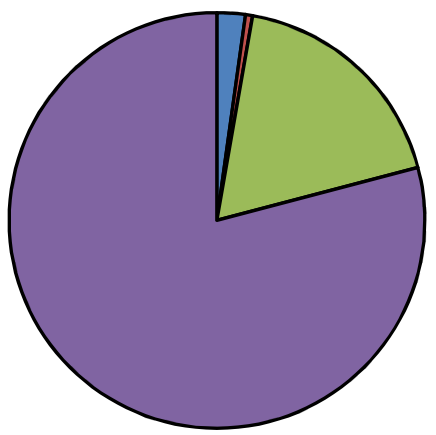

Lithuania

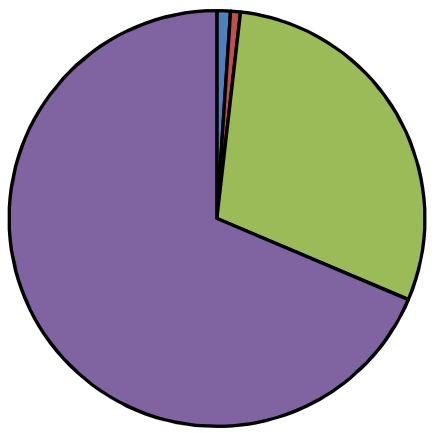

Czech Republic

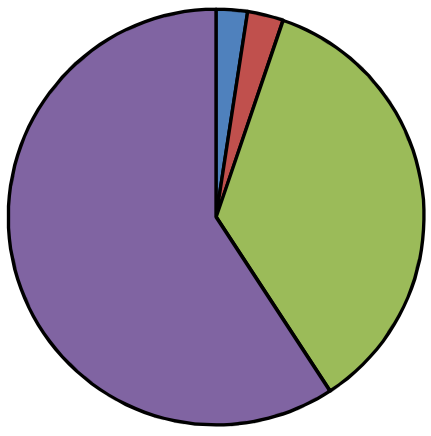

Latvia

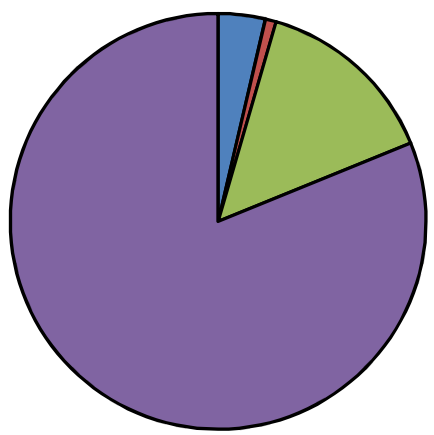

Hungary

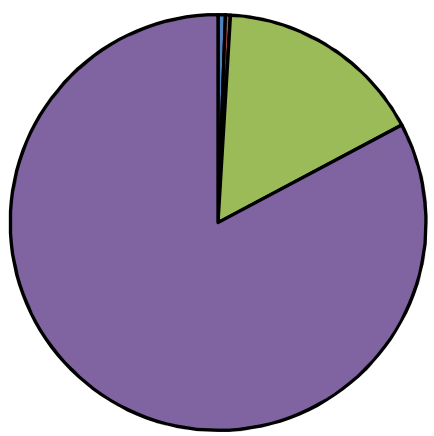



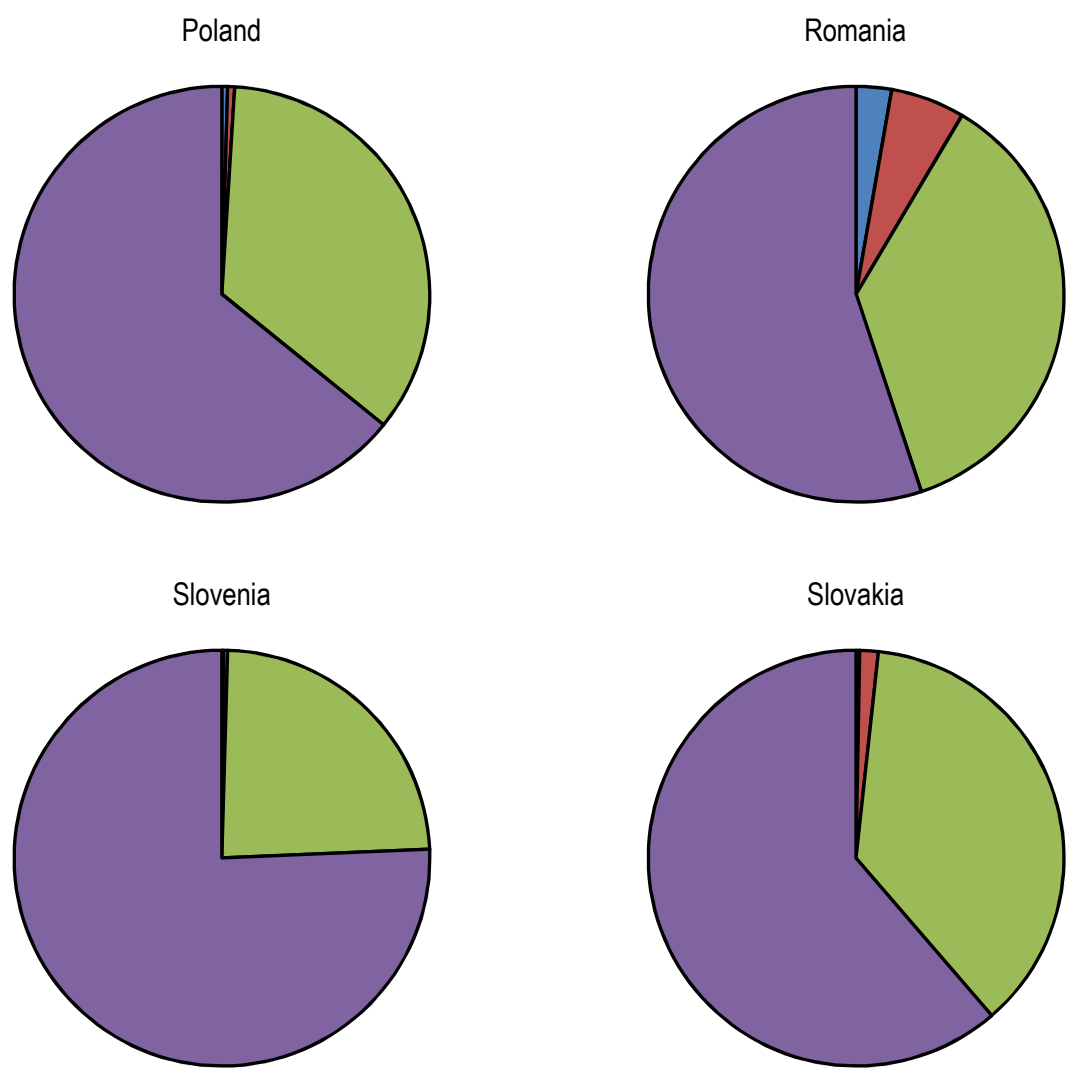

Source: Author's elaborations based on data provided by the Eurostat database. NACE R2. Sectors: Agriculture, forestry and fishing; Mining and quarrying; Manufacturing; Services. Partner: All countries of the world. 


\section{Appendix 2: Empirical estimates}

\section{Table 3 Determinants of Intra-EU Capital Flows Into the New Member States}

The estimated equation is:

$$
\begin{aligned}
& \operatorname{lnIDI}_{i i t}=\beta_{0} \operatorname{lnGDP_{it}}+\beta_{1} \operatorname{lnGDP}_{j t}-\beta_{2} \text { lndistance }_{i j}+\beta_{3} \text { lnopenness }_{j t}-\beta_{4} \ln R U L C_{j t}
\end{aligned}
$$

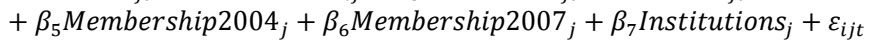

\begin{tabular}{|c|c|c|c|c|}
\hline Dependent variable: $\quad$ InIDI & (1) & (2) & (3) & (4) \\
\hline$\overline{\operatorname{lnGDP}}$ & $.014(.044)$ & $.019(.030)$ & $.003(.026)$ & $.005(.025)$ \\
\hline $\operatorname{lnGDP} P_{j}$ & $.048^{*}(.023)$ & $.050^{* *}(.022)$ & $.047^{*}(.023)$ & $.047^{*}(.023)$ \\
\hline Indistance & $-.018(.025)$ & $-.006(.027)$ & $-.021(.024)$ & $-.022(.024)$ \\
\hline Inopenness & $.007(.007)$ & $.007(.007)$ & $.009(.005)$ & $.009(.005)$ \\
\hline InRULC & $-.000(.006)$ & $-.000(.005)$ & $-.002(.005)$ & $-.002(.005)$ \\
\hline Membership 2004 & & $.208^{\star *}(.070)$ & $.253^{\star \star \star}(.060)$ & $.258^{* * *}(.066)$ \\
\hline Membership 2007 & & & $.424^{\star * *}(.052)$ & $.424^{\star \star *}(.049)$ \\
\hline Investment freedom & & & & $-.044(137)$ \\
\hline Constant & $3.67^{\star \star *}(.178)$ & $3.46^{\star * *}(.197)$ & $3.56^{* * *}(.192)$ & $3.76^{* * *}(.569)$ \\
\hline Obs. & 2506 & 2506 & 2506 & 2506 \\
\hline $\mathrm{R}^{2}$ & .002 & .014 & .024 & .024 \\
\hline
\end{tabular}

(i) In the estimated empirical model, InIDI $_{\text {iit }}$ denotes intra-EU direct investment from an EU-15 country j into a NMS-12 i at time $t$; (ii) $\operatorname{lnGDP} P_{\text {it }}$ denotes GDP of the source country $i$ at time $t$; (iii) $\ln G D P_{j t}$ denotes GDP of a host country $j$ at time $t$; (iv) lndistance lenotes $_{i j}$ the distance between the source and host capitals; ( $v$ )lnopenness $s_{i j t}$ denotes the openness of the host country $j$ at time $t$; (vi) $\operatorname{lnRULC}_{j t}$ denotes the real unit labour cost of host country $j$ at time $t$; (vii) Enlargement ${ }_{j}$ denotes the EU membership dummy; (vii) Institutions. The estimation sample contains 27 European countries over the period 1993-2013. The model was estimated with a lag of one period in the independent variables, with the exception of the constant. Cluster-robust standard errors in parentheses. *denotes significant at $10 \%$; ** at $5 \% ; * * *$ at $1 \%$. 


\section{Table 4 Determinants of Intra-EU Capital Flows Into the Baltic Countries}

The estimated equation is:

$$
\begin{aligned}
\operatorname{lnIDI}_{i i t}=\beta_{0} \operatorname{lnGDP}_{i t} & +\beta_{1} \operatorname{lnGDP}_{j t}-\beta_{2} \text { lndistance }_{i j}+\beta_{3} \text { lnopenness }_{j t}-\beta_{4} \text { lnRULC }_{j t} \\
& +\beta_{5} \text { Membership } 2004_{j}+\beta_{6}{\text { Membership } 2007_{j}+\beta_{7} \text { Institutions }_{j}+\varepsilon_{i j t}}
\end{aligned}
$$

\begin{tabular}{lcc}
\hline Dependent variable: $\operatorname{InIDI}$ & $(1)$ & $(2)$ \\
\hline InGDPi & $.003(.026)$ & $.003(.025)$ \\
InGDP & $.046^{*}(.023)$ & $.046^{*}(.023)$ \\
Lndistance & $-.027(.023)$ & $-.027(.023)$ \\
Lnopenness & $.009^{*}(.004)$ & $.009^{*}(.004)$ \\
InRULC & $-.002(.005)$ & $-.002(.005)$ \\
Membership 2004 & $.257^{* * *}(.059)$ & $.258^{* * *}(.065)$ \\
Membership 2007 & $.412^{* * *}(.055)$ & $.412^{* * *}(.056)$ \\
Baltics dummy & $-.028(.021)$ & $-.027(.025)$ \\
Investment freedom & & $-.152(.169)$ \\
Constant & $3.62^{* * *}(.187)$ & $2.90^{* * *}(.624)$ \\
\hline Obs. & 2506 & 2506 \\
\hline$R^{2}$ & .025 & .025 \\
\hline
\end{tabular}

(i) In the estimated empirical model, InIDI $_{\text {iit }}$ denotes intra-EU direct investment from an EU-15 country j into a NMS-12 $i$ at time $t$; (ii) $\ln G D P_{\text {it }}$ denotes GDP of the source country $i$ at time $t$; (iii) $\ln G D P_{j t}$ denotes GDP of a host country $j$ at time $t$; (iv) lndistance lenotes $_{i j}$ the distance between the source and host capitals; $(v)$ lnopenness $s_{i j t}$ denotes the openness of the host country $j$ at time $t$; (vi) $\operatorname{lnRULC}_{j t}$ denotes the real unit labour cost of host country $j$ at time $t$; (vii) Enlargement $t_{j}$ denotes the EU membership dummy; (vii) Institutions. The estimation sample contains 27 European countries over the period 1993-2013. The model was estimated with a lag of one period in the independent variables, with the exception of the constant. Cluster-robust standard errors in parentheses. *denotes significant at $10 \%$; ** at $5 \%$; *** at $1 \%$. 


\section{Table 5 Determinants of Intra-EU Capital Flows Into the Balkan Countries}

The estimated equation is:

$$
\begin{aligned}
& \operatorname{lnIDI}_{i i t}=\beta_{0} \operatorname{lnGDP_{it}}+\beta_{1} \operatorname{lnGDP_{jt}}-\beta_{2} \text { lndistance }_{i j}+\beta_{3} \text { lnopenness }_{j t}-\beta_{4} \ln R U L C_{j t} \\
& +\beta_{5} \text { Membership2004 }{ }_{j}+\beta_{6}{\text { Membership } 2007_{j}}+\beta_{7} \text { Institutions }_{j}+\varepsilon_{i j t}
\end{aligned}
$$

\begin{tabular}{lcc}
\hline Dependent variable: InIDI & $(1)$ & $(2)$ \\
\hline InGDPi & $.003(.026)$ & $.005(.025)$ \\
InGDP & $.047^{*}(.024)$ & $.046^{*}(.023)$ \\
Indistance & $-.023(.026)$ & $-.025(.026)$ \\
Inopenness & $.009(.005)$ & $.009(.005)$ \\
InRULC & $-.002(.004)$ & $-.002(.005)$ \\
Membership 2004 & $.252^{* * *}(.060)$ & $.256^{* * *}(.066)$ \\
Membership 2007 & $.428^{\star * *}(.051)$ & $.429^{* * *}(.049)$ \\
Balkans dummy & $-.006(.014)$ & $-.007(.013)$ \\
Investment freedom & & $-.048(.139)$ \\
Constant & $3.58^{* * *}(.213)$ & $3.79^{* \star *}(.578)$ \\
\hline Obs. & 2506 & 2506 \\
\hline $\mathrm{R}^{2}$ & .024 & .024 \\
\hline
\end{tabular}

(i) In the estimated empirical model, InIDI $_{\text {iit }}$ denotes intra-EU direct investment from an EU-15 country j into a NMS-12 i at time $t$; (ii) $\ln G D P_{\text {it }}$ denotes GDP of the source country $i$ at time $t$; (iii) $\ln G D P_{j t}$ denotes GDP of a host country $j$ at time $t$; (iv) lndistance $e_{i j}$ denotes the distance between the source and host capitals; $(v)$ lnopenness $s_{i j t}$ denotes the openness of the host country $j$ at time $t$; (vi) $\operatorname{lnRULC}_{j t}$ denotes the real unit labour cost of host country $j$ at time $t$; (vii) Enlargement $t_{j}$ denotes the EU membership dummy; (vii) Institutions. The estimation sample contains 27 European countries over the period 1993-2013. The model was estimated with a lag of one period in the independent variables, with the exception of the constant. Cluster-robust standard errors in parentheses. *denotes significant at $10 \%$;* at 5\%; *** at $1 \%$. 
Table 6 Determinants of Intra-EU Capital Flows Into the Countries of Central Europe

The estimated equation is:

$$
\begin{aligned}
& \operatorname{lnIDI}_{i i t}=\beta_{0} \operatorname{lnGDP_{it}}+\beta_{1} \operatorname{lnGDP_{jt}}-\beta_{2} \text { lndistance }_{i j}+\beta_{3} \text { lnopenness }_{j t}-\beta_{4} \ln R U L C_{j t} \\
& +\beta_{5} \text { Membership2004 }{ }_{j}+\beta_{6}{\text { Membership } 2007_{j}}+\beta_{7} \text { Institutions }_{j}+\varepsilon_{i j t}
\end{aligned}
$$

\begin{tabular}{|c|c|c|}
\hline Dependent variable: $\quad$ InIDI & (1) & $(2)$ \\
\hline $\operatorname{lnGDP} i$ & $.007(.027)$ & $.007(.026)$ \\
\hline $\operatorname{lnGDP} P_{j}$ & $.047^{*}(.023)$ & $.047^{*}(.023)$ \\
\hline Indistance & $-.019(.026)$ & $-.020(.026)$ \\
\hline Inopenness & $.009^{*}(.005)$ & $.009^{*}(.005)$ \\
\hline InRULC & $-.002(.005)$ & $-.002(.005)$ \\
\hline Membership 2004 & $.251^{* * *}(.060)$ & $.254^{* * *}(.065)$ \\
\hline Membership 2007 & $.429^{\star \star \star}(.054)$ & $.428^{\star \star *}(.051)$ \\
\hline Central dummy & $.016(.026)$ & $.015(.025)$ \\
\hline Investment freedom & & $-.024(.133)$ \\
\hline Constant & $3.53^{* * *}(.218)$ & $2.82^{\star \star \star}(.644)$ \\
\hline Obs. & 2506 & 2506 \\
\hline $\mathrm{R}^{2}$ & .024 & .024 \\
\hline
\end{tabular}

(i) In the estimated empirical model, ${ }_{\text {InIDI }}$ iit denotes intra-EU direct investment from an EU-15 country j into a NMS-12 $i$ at time $t$; (ii) $\ln G D P_{\text {it }}$ denotes GDP of the source country $i$ at time $t$; (iii) $\ln G D P_{j t}$ denotes GDP of a host country $j$ at time $t$; (iv) lndistance lij $_{i}$ denotes the distance between the source and host capitals; $(v)$ lnopenness $s_{i j t}$ denotes the openness of the host country $j$ at time $t$; (vi) $\operatorname{lnRULC} C_{j t}$ denotes the real unit labour cost of host country j at time $t$; (vii) Enlargement $t_{j}$ denotes the EU membership dummy; (vii) Institutions. The estimation sample contains 27 European countries over the period 1993-2013. The model was estimated with a lag of one period in the independent variables, with the exception of the constant. Cluster-robust standard errors in parentheses. *denotes significant at $10 \% ; * *$ at $5 \% ; * * *$ at $1 \%$.

Table 7 Correlation Matrix

\begin{tabular}{lcccccccc} 
& $\operatorname{InGDP}_{i}$ & $\operatorname{InGDP}_{j}$ & Indistance & InRULC & Inopen & Investfree & Enlarg. & Enlarg2. \\
\hline InGDP & 1 & & & & & & & \\
InGDP & 0.0000 & 1 & & & & & & \\
Indistance & -0.1201 & -0.2524 & 1 & & & & & \\
InRULC & 0.0707 & -0.0000 & 0.0548 & 1 & & & & \\
Inopen & 0.0856 & 0.0000 & 0.0718 & 0.0425 & 1 & & & \\
Investfree & 0.0056 & 0.0000 & -0.0832 & -0.0752 & -0.0773 & 1 & & \\
Enlargement & -0.0074 & 0.0000 & -0.0637 & -0.1009 & -0.0485 & 0.2694 & 1 & \\
Enlargement2 & -0.0015 & -0.0000 & 0.0955 & 0.1115 & 0.0088 & -0.0592 & -0.2719 & 1 \\
\hline
\end{tabular}

